\title{
SPECIFICITY OF COMMUNICATION PROCESS IN MILITARIZED EDUCATIONAL INSTITUTION
}

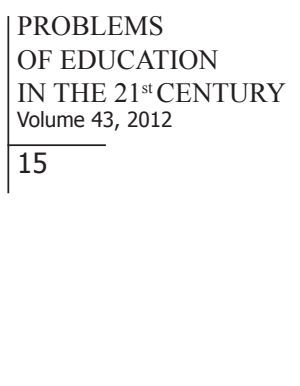

\author{
Alens Indriksons \\ State Border Guard College, Rezekne, Latvia \\ E-mail: alensindriksons@inbox.Iv
}

\begin{abstract}
Communication is the exchange of information between sender who send and receiver who decode it. In an organization communication flows in downward, upward, lateral, external and diagonal directions. Communication process in militarized educational institution has its own specificity. The most popular type of communication in a militarized educational institution is downward communication because of special rules which regulate the service relationship between the participants involved in the communication process. The disadvantage of this communication is limited feedback which is a very important component of the communication process and which plays an important role in the teaching process. It is impossible to reach the purpose of teaching process without feedback because learning is an active bilateral dynamic system. The present paper discovers problems in communication flow directions in militarized educational institution on the basis of Latvian State Border Guard College because college in its activities is guided by a number of rules which regulate and define teaching process and service condition.
\end{abstract}

Key words: communication, militarized educational institution, service.

\section{Introduction}

Today's environment of international safety is changeable, complicated and hard to predict. Therefore any political, social, military or economical instability even somewhere wide apart can directly or indirectly endanger the national safety of Latvia (The State Defensive Concept, 2011). In order to make Latvia ready to protect its external and internal safety, there is necessity for well- and professionally-trained personnel, being able to deal with new challenges. National Defence against outside enemy is ensured by the National Armed Forces, however the responsibility for internal safety is ensured by institutions of the Ministry of the Interior, which are militarized institutions. The Ministry of the Interior is the leading institution in home affairs sector which includes such sub-sectors as fight against crime, protection of public order and security, protection of individual rights and lawful interests, state border security, fire safety, fire security, rescue, civil protection, record keeping and documentation of population, as well as migration. (The Ministry of the Interior of the Republic of Latvia, 2008). Institutions under the subordination of the Ministry of the Interior are the following: the Security Police, State Police, State Border Guard, the State Fire-fighting and rescue Service, as well as colleges which are subordinated by these institutions (Law "On Service of Officials with Special Service Ranks Working in Institutions of the System of the Ministry of the Interior and the Prisons Administration", 2006). Colleges under subordination of the Ministry of the Interior are militarized educational institutions, which train the personnel for the performance of its specific tasks. A main specific feature of militarized educational institutions is the fact that the personnel who realize the study process and the one which acquires it, they are in official relations. By the term "official" we understand relations which are regulated by specific laws 
PROBLEMS

OF EDUCATION

IN THE $21^{\text {st }}$ CENTURY

Volume 43, 2012

and regulations, therefore the communication in these educational institutions is very specific.

The objectives of the paper are professional learning process and service conditions in one institution of the system of the Ministry of the Interior - State Border Guard and its subordinate educational institution - State Border Guard College.

The goal of the paper is to research specificity of militarized (organized like an army (Longman Exams Dictionary, 2006)) educational institutions which are working on the basis of principle of one man management and communication is influenced and regulated by professional rules and regulations.

The aim of this research is to analyze the procedure of communication process's action plan within the militarized educational institutions.

\section{Process of Communication, Its Action Plan}

Communication is an exchange and flow of information and ideas from one person to another; it involves a sender transmitting an idea, information, or feeling to a receiver (Communication and Leadership. The communication process, 1997). I. Ezera (2000) defines the process of communication as the exchange of information between two or several persons or groups; it serves for completing of transactions, promotes reaching of set targets and it is pointed towards mutual understanding. Communication is the transmission of information (Foss, Littlejohn, 2008). In order to make the communication happen, there shall be information which to transmit from one person to another by the use of various methods of information exchange. The communication is a bilateral process which is impossible without feedback from its members. Psychologist R. Jakobsons considers that the process of exchange of information or communication consists of six following elements:

1. Sender (coder) - a person, which delivers the information;

2. Receiver (decoder) - a person, which receives the information;

3. Contact - way of transmitting of information;

4. Message - the content of information;

5. Code - language and its rules, by which the information is delivered;

6. Context - real situation of communication, when the content of information is revealed fully (Pḷaveniece, Škuškovnika, 2002).

Communications needs a mutuality of understanding between sender and receiver (Principles of Effective Business Communication). S. Omārova (2002) stresses the fact that the communication is possible if the partner has the same or a similar system of information codification and decodification.

Important characteristics of communication are the following:

- Communication is a two way process.

- Communication always happens between or among two or more parties - sender and receiver.

- Communication involves an exchange of facts, ideas, feelings or thoughts.

- Communication uses verbal ways like words spoken or written, or non-verbal ways like gestures, postures, etc. (Principles of Effective Business Communication).

In an organization, communication flows in five main directions - downward (from a higher level in an organization to a lower level), upward (communication that flows to a higher level), lateral (communication that takes place at the same levels of hierarchy in an organization), diagonal (communication between a manager and employees of other workgroups) and external (communication between a manager and external groups such as suppliers etc.) (Communication Flows in an Organization, 2008). According to S. Omārova (2002), the term "organization" include state and educational institutions, factories and trading enterprises, the church and armed forces, because organizations are the large groups which ensure the production and distribution 
of material and mental values which circulate within the society, they stabilize the social order

and promote the development of whole society.

\section{Specific Features of Communication within Militarized Educational Institutions}

The main task of militarized educational institution is to make the personnel ready for practical service. In order to make the personnel ready to perform their duties professionally, everyone has to acquire a particular amount of skills and knowledge, which are determined within the Professional Standards, and the communication plays an important role for reaching of training goals. The latest researches are indicative of the fact that the mind is developing according to the surrounding environment, therefore within the education institutions the communication skills of pedagogues are the part of this surrounding environment (Churches, 2010). Pursuant to opinions of R. Powell and D. Powell (2010), the learning process is related to student abilities, student motivation and classroom communication. The communication process within the militarized education institution can be characterized in relation with vertical and horizontal communication, being reflected within the Figure 1:

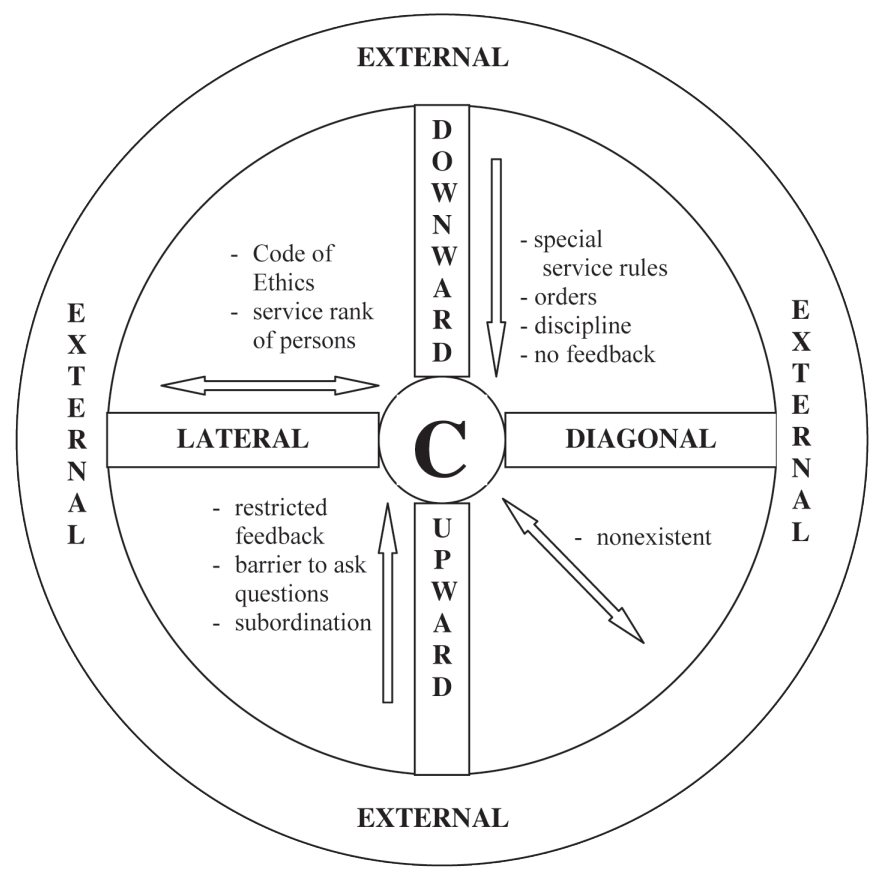

Figure 1: Process of Communication within Militarized Educational Institution.

In contradistinction to vocational education institutions which are subordinated by the Ministry of Education and Science, the militarized education institutions are subordinated by those ministries in the name of which they perform the realization of the educational process, and for the needs of which the personnel is being trained. The militarized educational institutions in the Republic of Latvia are subordinated by the Ministry of the Interior and they are working on the basis of the principle of one man management. Their activity is regulated by the law "On the Career Course of Service of Officials with Special Service Ranks Working in Institutions of the System of the Ministry of the Interior and the Prisons Administration" 
PROBLEMS

OF EDUCATION

IN THE $21^{\text {st }}$ CENTURY

Volume 43, 2012

18

prescribes the customs status of professional service in the institutions of the system of the Ministry of the Interior and the Prisons Administration in order to ensure legal, settled, effective and public activity of the institution. Regulations of State Boarder Guard prescribe that officials with special service ranks and employees who have contract of employment, within the State Boarder Guard work accordingly united hierarchical system, where the one official is subordinated to another (Regulations of State Boarder Guard, 2008). Therefore, the predominant manner of communication in these educational institutions is downward communication, which express itself as saying the words by the senior officials. This way of communication has a significant drawback - there is no feedback which is an important part of successful communication. The junior personnel, inter alia, lecturers, comply with the orders, but without any feedback, therefore this manner of communication can not be considered as communication that promotes the activity of the educational institution. Dubkevičs (2006) considers, that the one-way communication is quick, easy and uncomplicated, but at the same time it usually is ineffective. In this case it is impossible to give some proposals, make suggestions or draw attention to some failures, since the internal rules and regulations prescribe that orders can not be discussed, they have to be executed. This one-way communication shall not be admissible for training process, because, according to V. Zelmenis (2000), training process is a bilaterally active dynamic system, where the teacher teaches and the student learns; valuable results are possible only in case if the determined activity of both parties is ensured.

Upper communication means the flow of information from the lower levels of the organization to the higher levels of authority (Easy Communication, 2006). One of such ways of communication within the militarized educational institution is communication between lecturers and chiefs. An example of such communication could be situation when according to subordinate position, there is given an order to offer proposals for dealing with some issue. The situation is peculiar due to the fact that it happens only in militarized institutions, where the proposals have to be given apart from the fact whether they are efficient or problem-solving (they have to be given only because they have to be). If there are no proposals, it could be interpreted as a breach of the order.

All what happens in the classroom is created and sustained trough communication processes (Powell, Powell, 2010). As it was already mentioned before, upward communication shall be present between lecturers and cadets during the training process, because, according to conclusions made by Livits and Tešs after studying the efficiency of one-way and two-way communication models on their own, two-way communication is more effective and it allows to come to a united comprehension, avoiding wrong interpretations (Pl̦aveniece, Škuškovnika, 2002). At the same time, it should also be taken into consideration that there are official relations between the lecturers and the personnel and these relations are regulated by specific rules and regulations. It is not easy for students to break psychological barrier and to openly express their opinion regarding some issue to the senior (according his or her rank and position). It is connected with the strict order of subordination and frequently lecturers are considered as chiefs not assistants for acquiring of knowledge. Therefore the pedagogue often has to only watch students' non-verbal reaction and in such a way to determine, whether students have understood the material or not. In order to keep the official discipline, it is necessary to understand the distinction between official issues and issues concerning the content of a subject matter.

According to opinions of L. Dubkevičs (2006) persons' mutual perception is influenced by various factors: physical environment (distance, place), social environment (for instance, norms of social behaviour), physiological factors (motives, preconceptions, attraction of a partner, etc.). In its turn, T. Harris and M. Nelson (2008) point that each individual is an actor and a reactor of the communications events during the communication process. Mutual horizontal communication within the militarized educational institution is firstly pointed towards the rank and position of the collocutor; to a great extent it determines the content of conversation 
and model of communication. Horizontal communication within the State Boarder Guard is prescribed by particular regulating documents, for instance, "Code of Ethics for Officials and Employees of State Boarder Guard", where there are defined basic principles of professional ethics in order to promote valid, honest and qualitative discharge of official (work) duties. For example, Section 13, Paragraph 3 of the "Code of Ethics for Officials and Employees of State Boarder Guard" (2008) prescribes that an official (an employee) observes professional etiquette during his or her mutual communication and he or she does not use words, gestures and waves which could injure somebody's pride and which do not correspond the way of professional communication. Mutual communication within a horizontal level is also prescribed by separate regulatory enactments, which state the procedure of communication with officials with special service ranks when they are wearing the uniform.

M. Plavniece (2002) considers that in order to make the chief being able to perform his or her duties effectively, he or she has attributed a power. A diagonal communication between chiefs and indirectly subordinate employees is prescribed within the Section 9 of the "Regulations of State Boarder Guard", where it states that the chief of the State Boarder Guard gives orders only to directly subordinate officials and chiefs of directly subordinated units. It is also mentioned that the chief of the State Boarder Guard can exclusively give direct orders to any official or employee of the State Boarder Guard. (Regulations of State Boarder Guard, 2008). Therefore it is determined that in the real service the diagonal communication almost do not occur, because all issues are being solved accordingly strict hierarchy. Sometimes it impedes fast solving of issues, because the prescribed rules do not provide a diagonal communication within the militarized institutions.

\section{Conclusion}

Militarized educational institutions are specific by the fact that they are working on the basis of the principle of one man management; therefore the communication is influenced and regulated by professional rules and regulations. The predominant model of communication in militarized educational institutions is one-way downward communication. Such a model does not promote the successful activity of the institution, since the process of communication is uncompleted due to the lack of feedback. A feedback upward communication between lecturers and students is bothered because students of militarized educational institutions often have psychological difficulties during the communication with pedagogues of higher rate or position during the process of teaching. Due to the fact that communication members of militarized educational institutions have official relations, the horizontal communication is prescribed by specific regulatory acts, and during the communication the attention is paid to the rank and position of the partner. There is almost no diagonal communication within the members of the militarized educational institution, since the official rules and regulations do not prescribe such way of communication due to the determined procedure of giving and executing of orders.

To enhance the results of learning process and institution's activities, it is necessary to avoid the communication problems in militarized educational institutions and carry out further research on the possibility of improving communications. As one of the possible directions of the research might be possibility to make changes in the special laws and regulations, which would anticipant for lecturers such privileges as civil dress wearing during lessons in the classroom, the academic freedom charter and service subordination to the learning process. 
PROBLEMS

OF EDUCATION

IN THE $21^{\text {st }}$ CENTURY

Volume 43, 2012

\section{References}

Churches, R. (2010). Effective Classroom Communication. Hampshire: Efex. Ltd

Communication Flows in an Organization. (2008). Retrieved May 10, 2012, from http://www. managementstudyguide.com/communication-flows.htm

Communication and Leadership. The communication process. (1997). Retrieved May 14, 2012, from http://www.nwlink.com/ donclark/leader/leadcom.html

Code of Ethics for Officials and Employees of State Boarder Guard. (2008). Retrieved May 15, 2012, from http://www.rs.gov.lv/bildes_upl/VRS\%20etikas\%20 kodekss.pdf

Dubkevičs, L. (2006). Saskarsme audzēkņiem. Riga: Jumava.

Easy Communication. Upward communication. (2006). Retrieved May 17, 2012, from http:// easycommunication.info/communication/upward-communication

Ezera, I., Graudiņa, I., \& Dreiberga, S. (2000). Lietišķā komunikācija. Riga: Kamene.

Foss, K. A., \& Littlejohn, S. W. (2008). Theories of Human Communication. Belmont: Thompson Wadsworth.

Harris, T. E., \& Nelson, M. D. (2008). Applied organizational Communication. New-York: Taylor \& Francis Group.

Law "On Service of Officials with Special Service Ranks Working in Institutions of the System of the Ministry of the Interior and the Prisons Administration”. (2006). Retrieved May 16, 2012, from http://www.likumi.lv/doc.php?id=138750

Longman Exams Dictionary (2006). Harlow: Pearson Education Limited.

Omārova, S. (2002). Cilvēks runā ar cilvēku. Riga: Kamene.

Omārova, S. (2002a). Cilvēks dz̄̄vo grupā. Riga: Kamene.

Pḷaveniece, M., \& Škuškovnika, D. (2002). Sociālā psihologija pedagogiem. Rīga: Raka.

Pḷavniece, M. (2002). Saskarsme. Riga: Jumava.

Powell, R. G., \& Powell, D. L. (2010). Classroom Communication and Diversity. New-York: Taylor \& Francis Group.

Principles of Effective Business Communication. Retrieved May 15, 2012, from http://www. financedoctors.net/Notes/114.pdf

Regulations of State Boarder Guard (2008). Retrieved May 16, 2012, from http://www.rs.gov.lv/doc_upl/ VRS\%20reglaments\%2021.05.2010.pdf

The Ministry of the Interior of the Republic of Latvia (2008). Retrieved May 15, 2012, from http://www. iem.gov.lv/eng/

The State Defensive Concept (2011). Retrieved May 15, 2012, from http:/www.mil.lv/ /media/NBS/ PDF/VAK_projekts_100412.ashx

Zelmenis, V. (2000). Pedagogijas pamati. Riga: RaKa.

Advised by Velta L,ubkina, Rezekne Higher Education Institution, Rezekne, Latvia

Received: May 05, 2012

Accepted: June 12, 2012
Master of Pedagogy, Lector, Border Guard and Immigration Service Department, State Border Guard College, Zavoloko 8, Rezekne, Latvia.

E-mail: alensindriksons@inbox.lv; Website: http://www.vrk.rs.gov.lv 